\title{
Happy In The Informal Economy? A Case Study Of Well-Being Among Day Labourers In South Africa
}

\author{
Phillip Blaauw, University of Johannesburg, South Africa \\ Ilse Botha, University of Johannesburg, South Africa \\ Rinie Schenck, University of the Western Cape, South Africa \\ Christie Schoeman, University of Johannesburg, South Africa
}

\begin{abstract}
Past research provided evidence of the negative effect that individual unemployment can have on subjective well-being. The persistent high levels of unemployment and poverty in South Africa have been well documented. Many people are forced into the informal economy, where they engage in a variety of survivalist activities such as day labouring. As no previous study has been conducted on the well-being of day labourers, the aim of this paper is to investigate the determinants of the well-being of South African day labourers. Objective and subjective functions are compared to determine the role of income and other variables in the well-being of day labourers. The determinants are categorised according to economic, comparison and attitudinal variables. The objective function uses income and the subjective function uses the binary measure of 'experiencing a good week in terms of wages' as dependent variables. The results showed that comparison variables are important determinants for the subjective measure of well-being, and attitudinal variables are important for the objective measure of well-being. The economic variables were important in both functions. The findings of this paper confirm other research findings showing that personal income is important for well-being in a poor community. The difference between these functions indicates that the subjective and objective measures of wellbeing both capture valuable characteristics of subjective well-being $(S W B)$ in a poor community.
\end{abstract}

Keywords: Day Labouring; Well-Being; Happiness; Informal Economy

\section{INTRODUCTION AND AIM OF THE PAPER}

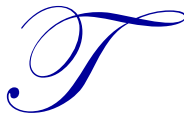

here was a time when the study of well-being, and subjective well-being in particular, was, for the most part, excluded from economic analysis as a result of the disciplinary paradigm of logical positivism. Yet, economic theories often include reference to values, expectations, and the like (Easterlin 2001: 225).

Since the 1940s, the landscape has changed and, recently, Helliwell and Barrington-Leigh (2010) have argued that growing awareness is being raised in academic, policy, and public areas to subjective measures of wellbeing. This represents an important shift towards greater realism in the study of economic behaviour. Subsequently, a significant body of literature emerged on the determinants of well-being in developed countries. Recent research findings on well-being in developing countries specifically have added more depth to the development debate (Tiwari 2009: 129).

Most studies on subjective well-being in transitional economies focus on either rural areas or gender groups. Prominent scholars in South Africa ensured that South Africa's transitional experience and its influence on well-being form part of this important research agenda (Møller and Schlemmer, 1989; Møller, 1998; Møller and Saris, 2001; Møller and Dickow, 2002; Ebrahim, Botha, and Snowball, 2011; Botha and Booysen, 2011). A constant theme in South African literature is that, in the main, the wealthier testify to higher levels of satisfaction and 
happiness than the worse-off. The most credible rationalization for the South African quality-of-life environment is the significant gap in living standards between rich and poor (Møller and Dickow, 2002). Møller and Saris (2001) emphasise this by providing an example of people of the Western Cape being as rule happy, satisfied and optimistic. On the other hand, people in the Eastern Cape, a province with the high levels of unemployment and deep poverty, are principally unhappy, dissatisfied, and pessimistic.

Cramm, Møller, and Nieboer (2010: 1013) state that there is a scarcity of research on well-being among the poorest of the poor. As a result, the experiences in terms of the well-being of marginalised groups in the South African labour market have not received sufficient attention in South African research on the subject.

Past research results provided evidence of the negative effect that individual unemployment can have on subjective well-being (Winkelmann, 2009: 421). The persistent high levels of unemployment and the severity of absolute poverty in South Africa have been well documented. As a result, many people are forced into the informal economy where they engage a variety of survivalist activities. Offering their labour on street corners and at intersections as day labourers is a pertinent example in this regard. Blaauw (2010) found no pure economic rationale for the sustainability of this activity, given the cost and the low and uncertain levels of income in this market, yet many day labourers have been involved in this activity for many years. Researching the well-being in this informal labour market is an important extension of the research into the employee side of the informal economy. It takes cognisance of subjective sociological and psychological factors as well, which hypothetically may be elements of an economic motive, explaining the continued sustainability of this activity.

No previous study has been conducted on the well-being of those involved in this informal labour market activity. This paper fills this void in the literature by investigating the well-being of day labourers in South Africa. The research will focus on the relationship between income and subjective well-being of South African day labourers in order to establish the important determinants of the subjective well-being of participants in this informal labour market activity. In doing so, the paper contributes to informing policy debates in South Africa and in the region on issues of social protection and quality-of-life for workers in this extreme form of casualised employment. The hypothesis that emerges from the literature is that economic variables play a defining role in the well-being of poorer communities.

\section{LITERATURE REVIEW}

Conventional wisdom around the effect of income on happiness is divided. The traditional view of money and happiness is that money has little impact on happiness. In fact, intellectuals and philosophers (e.g. Rousseau in 1762) have warned through the ages that wealth spoils the mind and is therefore not good for one (Hirata, 2011: 23). In a seminal article, Easterlin (1974) postulated that well-being measures are not related to national wealth. This finding was based on a small sample of nations (Diener, Lucas, Schimmack, and Helliwell, 2009: 164). This view, however, has constantly been challenged by empirical findings to the contrary (Cummins, 2000: 133). It is now accepted that there is a relatively strong correlation between well-being and national income levels.

Results on an individual level are slightly more complicated, as the correlation coefficients are, to some extent, difficult to interpret. There are, however, strong theoretical grounds to expect that income will be associated with well-being, especially in the case of poorer people (Diener, Lucas, Schimmack, and Helliwell, 2009: 86). Cummins (2000: 151) found that personal income is important for subjective well-being, especially for people who are poor. This was confirmed by Nielsen Paritski and Smyth (2010). The positive relationship between happiness and absolute income is considered to be one of the best-known findings in the literature (Ebrahim, Botha, and Snowball, 2011: 5; Hirata, 2011: 28). Diener, Sandvik, Seidlitz, and Diener (1993: 216) also found that income is correlated with subjective well-being in lower-income countries. The effect of income on happiness is more pronounced in developing countries than in developed countries, since once a certain threshold of income is achieved in developed countries, higher income does not aid higher levels of well-being (Clark, Frijters, and Shields, 2008).

In spite of the fact that standard microeconomic theory usually views utility as a function of own absolute income, some economists have proposed models in which the income of others enters the individual's utility 
function (Kingdon and Knight, 2007). After the literature acknowledged the link between income and happiness, the debate shifted focus to the relative or absolute nature of the relationship (Veenhoven, 1991; Diener et al., 1993). The absolute argument has as its premise in view that “... income helps individuals meet certain universal needs and therefore that income, at least at lower levels, is a cause of subjective well-being. The relativity argument is based on the idea that the impact of income or other resources depends on changeable standards such as those derived from expectancies, habituation levels, and social comparisons" (Diener et al., 1993). There is at present significant empirical evidence for the belief that subjective well-being depends on relative income, as well as defined by the reference group or the reference timeframe that people have in mind (Kingdon and Knight, 2003; 2007). Happiness is therefore strongly affected by status in society (Clark et al., 2008; Ebrahim et al., 2011).

Absolute and relative income is not the only economic determinant of happiness (Kingdon and Knight, 2003). The multifaceted nature of subjective well-being is now recognised in the literature, where subjective wellbeing is associated with a range of social, economic, and cultural characteristics of nations (Diener, Diener, and Diener, 2009). An excellent review of the factors emerging from documented research can be found in Diener, Sue, Lucas, and Smith (1999). Frey and Stutzer (2002), as well as Dolan, Peasgood, and White (2008), also provide reviews on the large economics literature on the determinants of happiness.

Determining factors identified in the literature, apart from absolute and relative levels of income, include religious activities, social trust, physical exercise, health, and marital status (Botha and Booysen, 2011: 3). Demir and Weitekamp (2007: 182-183) proposed a grouping of three main factors that influence happiness; namely, the happiness set point (assumed to be heritable, fixed, and stable over time), circumstances (geographical, demographical, and contextual variables), and intentional activities (voluntary and purposeful actions by individuals).

These factors play a role in both rich and poor geographical areas. Even amidst the severe poverty of rural China, factors such as attitudes, social comparisons, and aspirations influence the subjective well-being of the local inhabitants (Knight, Song, and Gunatilaka, 2009: 635).

In the South African context, Greyling (2011) identified issues such as service delivery, levels of human development, social relations, material well-being, and issues of governance and safety as important aspects, explaining the variation in the quality-of-life scores of people in the Gauteng City region (GCR). A further distinguishing aspect to keep cognisance of for this study is the possible impact of migratory status, especially given that a meaningful proportion of our sample consisted of migrant day labourers. The literature reveals that some important additional elements come to the fore when the subjective well-being of migrant workers is analysed. Gao and Smyth (2010: 1) found that expectations with regard to prospective future income are a central determinant of happiness for migrant workers in China. Their finding is “... suggests that many migrants expect their financial position and, by extension, their lives more generally to get better in the future and that this is having a positive effect on their current levels of happiness. The effect of optimistic expectations outstrips any realistic increase in own income." A study with potentially important implications for the level of subjective well-being prevailing in the day labour market in South Africa is that of Knight and Gunatilaka (2008). Using 2002 CIPS data, they tried to elucidate why the mean happiness score of rural-urban migrants is lower than that of those who stay behind in the countryside and of those who have an urban household registration. The authors explain that the aspirations of migrants mount in the cities. However, in many cases their expectations exceed their achievements (Gao and Smyth, 2010). This raises the question as to what the position in South Africa would be, given the acute levels of poverty.

The possible variables emerging from the literature will provide the theoretical motivation for the selection of the variables for the empirical section of the study. The nature of the day labour market in South Africa is discussed next to contextualize the empirical study and results.

\section{The Day Labour Market In South Africa}

One of the most visible forms of precarious employment in South Africa is day labouring as an informal economy activity, which has emerged in recent years. Workers congregate on street corners in all cities or towns in the country, seeking temporary employment for the day or for a limited extended period. In the United States, 
immigrant workers (mostly from Latin America) use this job-seeking strategy to get a foothold in the economy of their host country. In South Africa, on the other hand, this informal labour market activity is mainly the catchment area of those who have lost their job in the formal economy and who are unable to secure reemployment there, although immigrants from the rest of Southern Africa also join this informal labour market and compete with their South African counterparts for the available temporary employment on offer. In South Africa research on this informal labour market has been done by Schenck and Louw (2005) as well as Blaauw et al. (2006) and Blaauw (2010). It was estimated that in 2005-2006, at least 45,000 people, mostly male and African, congregated at more than a 1,000 places in South Africa to seek casual employment (Blaauw, 2010). The day labourers earn low and uncertain levels of income, leaving many of them in a state of deprivation and poverty. This informal labour market activity formed the basis for a country-wide survey to investigate the socio-economic position of such labourers in the broader South African economy. The results of the survey provided the opportunity to investigate the determinants of subjective well-being in this part of the informal economy of South Africa.

\section{SURVEY METHODOLOGY}

Valenzuela, Jr., Theodore, Meléndez, and Gonzalez (2006) conducted a nationwide study among day labourers in the United States. The study entailed a country-wide survey of 2,660 day labourers. These workers were randomly selected at 264 hiring sites in 139 municipalities in 20 states and the District of Columbia (Valenzuela, Jr. et al., 2006: i). The methodological approach in their study represents the best practice in terms of survey research in such a fluid environment. The South African survey followed the same methodology as the American study as far as it was possible.

The day labour market is extremely fluid. New workers enter this market daily and existing day labourers leave it simultaneously. Therefore, some hiring sites shrink in size or disappear altogether, while new ones surface at the same time (Valenzuela, Jr. et al., 2006: 4). To address these issues, Valenzuela, Jr. and his co-researchers aimed to identify as many day labour sites as possible, develop a random sampling frame, and employ a screening mechanism, allowing them to identify day labourers (Valenzuela, Jr. et al., 2006: 27). This process was adapted for the South Africa situation.

In line with the method of Valenzuela, Jr. et al. (2006), in 2005 and 2006, researchers associated with the present study went around the country and physically counted the number of day labourers in the various cities and towns and conducted preliminary interviews, using a short set of structured questions. In a follow-up survey, the researchers recorded the names of the streets where the day labourers congregated and counted the number of day labourers present at each site (Blaauw, 2010: 75).

The national census of the day labour workforce in South Africa represents a snapshot of this workforce at that particular time. It could not incorporate workers who might enter or leave this informal labour market during a particular year. Therefore, the number reported is likely to be higher if we were to replicate the survey in subsequent years or if one was able to measure workers who participate in this market during a one-year period. The important implication of this is that the estimated numbers will undercount the total size of the day labour workforce since they do not account for workers who were hired prior to the time that the count was taken or workers who regularly use the hiring site but for some reason did not search for work on the day when we surveyed (Valenzuela, Jr. et al., 2006: 4). The 2005-2006 survey of day labourers showed that there were close to 1,000 locations in South Africa ${ }^{1}$ where people were picked up and an estimated 45,000, mostly African men, stood at these sites looking for income each day. ${ }^{2}$

The sampling procedure was guided by the same doctrine that guided the sampling technique used by Valenzuela, Jr. et al. (2006) and adapted by Blaauw et al. (2006) and Louw (2007). It was impossible to compile an

\footnotetext{
${ }^{1}$ See Harmse, Blaauw and Schenck (2009:362) for a detailed description of the locations at municipal level.

2 This estimate is the minimum number of day labourers observed during the course of the survey. It sometimes happened that when a member of the project team arrived at a particular hiring site later in the day, only a few men were still standing there. The remaining day labourers would then indicate that many more men usually stood at that site, but that they had been hired for the day or had left already.
}

638 Copyright by author(s) Creative Commons License CC-BY

2013 The Clute Institute 
all-inclusive list with the names of all the day labourers in South Africa due to their persistently changing numbers and the flexible nature of this form of labour. A whole host of variables relating to geographic area, size and nature of hiring sites had to be taken into account in selecting a representative sample of day labourers in South Africa. The capitals of all provinces and important hubs in the rural areas had to be covered proportionally in terms of the number of day labourers present. A process of cluster sampling as a probability sampling technique was considered to be the most appropriate for the survey (Rubin and Babbie, 1997: 259; Bless and Higson-Smith, 1995: 93). Clustering had to take place both in terms of the number of day labourers interviewed in each centre, as well as the size of the various hiring sites in order not to over-represent rural in comparison to urban areas and big hiring sites in comparison to small sites and vice versa. This is deemed to be the best practice to ensure a sample that is as representative as possible of the characteristics of the research population (Valenzuela, Jr. et al., 2006). Another important measure to ensure that the results of the survey are as unbiased as possible was the conducting of a pilot study in a smaller geographical area (Blaauw et al., 2006). Following the same best practice, the results of the pilot study and the main survey for Pretoria were compared and yielded consistent results that are complementary and not contradictory. ${ }^{3}$

In practice, the sampling process also had to entail the use of some convenience sampling when appropriate. If a fieldworker, for example, travelled through a small town toward one of the sampled towns in order to conduct the interviews and saw a small number of day labourers in that town, he or she was instructed to conduct interviews with some of the day labourers present. This gave the survey improved representativeness in terms of the number of towns that were covered in the procedure, without falling into the trap of not being able to evaluate the 'goodness' or reliability of the sample as explained by Williams, Sweeney, and Anderson (2006: 301).

A sample of 10 percent was regarded as sufficient to control for possible sampling error (De Vos, Strydom, Fouche and Delport, 2004: 200). For the sample to be accepted as representative, between five and 10 percent of the research population had to be interviewed countrywide. A proportional sample of nine percent was set as a target for a suitable sample size for the number of interviews to be conducted in the various cities and towns in South Africa. It was estimated that a total of between 2,500 and 4,000 interviews had to be conducted across South Africa in order for a representative sample of the research population to be obtained.

The fieldwork was conducted from the end of February 2007 and was completed by the end of November 2007. Fieldworkers visited the predetermined hiring sites and randomly interviewed day labourers congregated there at the time. A total of 3,830 questionnaires were accepted for the study, representing no less than 8.5 percent of the research population.

One of the key ethical elements of the survey was not to keep any day labourer from accepting an employment opportunity due to his participation in the interview. This meant that, in some cases, interviews were not completed in their entirety. Rather than lose the gained data by completely discarding the questionnaire, however, it was decided that the data that was gathered in the course of the (truncated) interview would be included. Including these incomplete questionnaires, however, meant that the data had to be cleaned in order for a complete sample fit for cross-sectional regression analysis to be obtained. After this process was completed, the sample size was 2645 .

The following sections describe the basic descriptive statistics of day labourers in South Africa in 2007. What then follows is a discussion of the model and its estimation.

\footnotetext{
${ }^{3}$ In spite of the precautions, it is always imperative to be aware of the limitations of the approach in terms of statistical interference.
} 


\section{Descriptive Statistics Of Day Labourers In South Africa}

Demographic Features And Employment History

Table 1 presents a summary of the basic demographic characteristics of the day labourers from the survey.

Table 1: Demographic Profile Of Day Labourers In South Africa (2007)

\begin{tabular}{|c|c|}
\hline Country Of Origin & $\begin{array}{l}\text { South Africa: } 85.0 \text { Percent } \\
\text { Zimbabwe: } 9.5 \text { percent } \\
\text { Mozambique: } 2.6 \text { percent } \\
\text { Lesotho: } 1.4 \text { percent }\end{array}$ \\
\hline Gender & $\begin{array}{l}\text { Male: } 96.4 \text { percent } \\
\text { Female: } 3.6 \text { percent }\end{array}$ \\
\hline Race & $\begin{array}{l}\text { African: } 92.0 \text { percent } \\
\text { Coloured: } 7.3 \text { percent } \\
\text { White \& Indian: } 0.7 \text { percent }\end{array}$ \\
\hline Age & $\begin{array}{l}\text { Younger than 30: } 47.1 \text { percent } \\
\text { Between } 30 \text { and } 35: 22.9 \text { percent } \\
35 \text { and older: } 30 \text { percent }\end{array}$ \\
\hline Education & $\begin{array}{l}\text { No schooling: } 6 \text { percent } \\
\text { Some primary schooling: } 18.7 \text { percent } \\
\text { Completed primary schooling: } 9.2 \text { percent } \\
\text { Some secondary schooling: } 48.7 \text { percent } \\
\text { Completed secondary schooling: } 4.8 \text { percent } \\
\text { Post-school qualification: } 1.9 \text { percent }\end{array}$ \\
\hline Marital status & $\begin{array}{l}\text { Never married/single: } 56.1 \text { percent } \\
\text { Married: } 26 \text { percent } \\
\text { Living with a partner: } 9.9 \text { percent } \\
\text { Separated/divorced: } 5.6 \text { percent } \\
\text { Widowed: } 1.5 \text { percent }\end{array}$ \\
\hline $\begin{array}{l}\text { Dependents } \\
\text { Number of children }\end{array}$ & $\begin{array}{l}\text { Average }=4 \\
\text { Average }=2\end{array}$ \\
\hline Living conditions & $\begin{array}{l}\text { Living with their family: } 52 \text { percent } \\
\text { Living in permanent structures: } 32 \text { percent }\end{array}$ \\
\hline Employment history & $\begin{array}{l}\text { Had a full-time job before: } 51 \text { percent } \\
\text { Hired more than } 3 \text { times by same employer as day labourer: } \\
\text { Never: } 10 \text { percent } \\
\text { Seldom: } 50 \text { percent } \\
\text { Sometimes: } 25 \text { percent } \\
\text { Often: } 15 \text { percent }\end{array}$ \\
\hline
\end{tabular}

Source: Survey data

As was expected, the day labourers were almost exclusively male. The racial composition reveals that it is principally African and Coloured members of the population who engage in day labouring as an informal economic activity. This reflects the overall racial composition of the broader informal sector in South Africa as identified by Saunders (2005). The vast majority of day labourers can be classified as young. This is a manifestation of the persistent unemployment and under-employment among the young of South Africa (Vakalisa, 2005: 53). Each day labourer supports an average of four people, excluding himself. These dependants also do not necessarily live in the same province as the day labourer, which shows the migratory nature of this informal labour-market activity. It is estimated that this informal labour market provides some income for at least 170,000 people (Blaauw, 2010). 
Income

Table 2 provides a summary of the earnings of day labourers in South Africa in a good week in 2007.

Table 2: Means Of Earnings In A Good Week, In Rand (ZAR)

\begin{tabular}{|l|l|l|l|}
\hline & Mean & Mean \\
\hline Age & & Qualification & \\
\hline Age group: under 20 & 271 & No schooling & 379 \\
\hline Age group: 21-25 & 373 & Some primary schooling & 314 \\
\hline Age group: $26-30$ & 397 & Completed primary school & 367 \\
\hline Age group: $31-35$ & 410 & Some secondary schooling & 362 \\
\hline Age group: $36-40$ & 390 & Completed secondary school & 543 \\
\hline Age group: $41-45$ & 411 & Post-school qualification & 547 \\
\hline Age group: $46-50$ & 333 & & \\
\hline Age group: 51-55 & 365 & Employment History & \\
\hline Age group: $56-60$ & 288 & Have held a full-time job & 348 \\
\hline Age group: over 60 & 382 & Have never held a full-time job & 422 \\
\hline
\end{tabular}

Source: Survey data, adapted from Blaauw \& Krugell (2011).

A significant characteristic of the day labour market in South Africa is the unstable and uncertain levels of income prevalent in this informal labour market. This is illustrated in Figure 1.

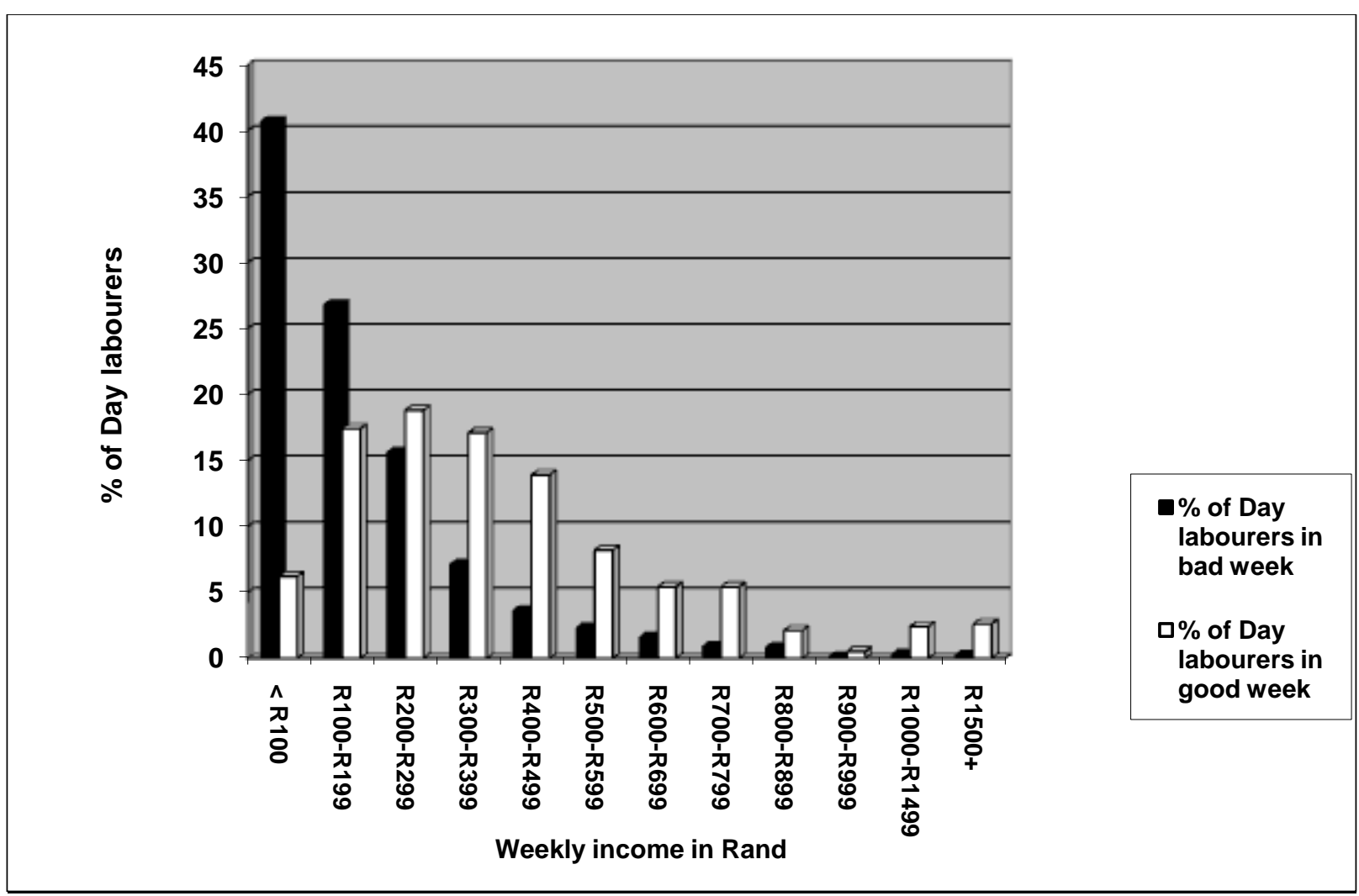

Figure 1: The Income Earned By Day Labourers In South Africa In A Good Week Versus A Bad Week, 2007

Source: Survey data

Theory suggests that this must definitely have an influence on the subjective well-being of day labourers in South Africa. This instability forms the key element for the model selection and empirical analysis described in the next section. 


\section{MODEL SPECIFICATION AND ESTIMATION}

The income-happiness relationship has, for some time, attracted the attention of economists (Mentzakis and Moro, 2009). Many researchers have concluded that personal income has little influence on subjective well-being (Cummins, 2000: 133) since it is an objective measure. According to Knight et al. (2009), satisfaction with household income is one possible measure of subjective well-being (SWB). However, the specific contribution of low income is uncertain when there is poor health and prolonged periods of unemployment. According to Cummins (2000: 134-135), there are two systematic reasons: 1) Subjective variables tend to share more variance with subjective variables than objective variables; thus it is less likely to find variance contributed by the objective variables (income), and 2) objective variables might change the strength of correlation between subjective variables.

To address the objective vs. subjective debate, this paper uses two functions; namely, a subjective and an objective function. The difference is the dependent variable. The first function will be a subjective function with the satisfaction level of income (is your income as good as expected?) as the dependent variable. At first glance, one may think that this answer shows just the comparison between the actual and expected income and, therefore, that it is far from subjective well-being. The argument would be that even if the actual income is as good as expected, it does not necessarily mean that the individual is satisfied or happy with it.

The use of this variable is justified, given the unique characteristic of this informal labour market activity. Research has shown that there are no traditional economic considerations, such as optimality and wealth creation, involved in this activity. The activity itself creates very little, if any, long-term wealth. From a micro-economic perspective, there is no economic rationale for participation in this activity; it is merely a survival strategy for those involved in it (Blaauw, 2010). Day labouring in South Africa is a reaction to a formal economy that is unable to clear the supply of labour, as predicted by classical labour-market theory. Day labouring is a catchment of this overflow, permanent in nature, and with every possibility that the participants will become more and more isolated from the formal economy.

Day labourers are painfully aware that the labour supply in their market is constantly increasing. The possible day-labour income is to be shared among an ever-growing day-labour force and a constantly diminishing level of real earnings in this labour market is expected (Blaauw, 2010). This argument is supported by the fact that reservation wages are constantly falling across many informal labour markets (Theodore, 2009). If a day labourer says his income is as good as, or better than expected, it shows a level of subjective satisfaction, given the knowledge that this is not the case for many of his counterparts and the uncertainty and variance in the income of the respondents (see Figure 1). This was a constant theme in discussions with the respondents and convincingly motivates the use of this variable in the subjective function.

The second function will be the objective function, where the log of the best wage earned per day is the dependent variable. The motivation for using an income variable in the objective function stems from the literature which suggests that income is a very important indicator of well-being in poor communities (Cummins, 2000). Given the low and uncertain income earned, on average, by the day labourers, it follows that at times when they do earn the best income levels in their labour market, this will bring about a feeling of happiness and improved SWB.

In the survey, day labourers were asked what the minimum amount was they were prepared to work for. The data showed day labourers often have to work for much lower wages than that, rendering the reservation wage to be more of a desired wage than the reservation wage known in economic theory (Blaauw, 2010). If they were able to obtain or get close to this wage, it would increase their level of subjective well-being. The best wage earned per day in the preceding months before the interview revealed a much closer correlation to the desired wage per day as expressed by the day labourers, rendering this variable the one best suited for this exercise. Both these functions will have the same explanatory variables.

\section{Explanatory Variables}

This model is based on the research done by Mentzakis and Moro (2009) as well as Knight, Song, and Gunatilaka (2009). It explicitly focuses on the potential important role of the economic variables in the well-being of 
very poor sections of the population as proposed by Cummins (2000). Other variables were included to act as control variables, but also to emphasise the important role that a range of non-economic factors may also potentially play in the explanation of subjective well-being (Kingdon and Knight, 2004:11-12).

The two functions will be specified according to the basic approach in the literature, including basic variables, conventional economic variables, comparison variables, community variables, and attitudinal variables as explanatory variables. The following variables from the day labourer survey were used and classified according to their broad categories.

\section{Basic Variables}

The basic demographic variables appear as standard throughout the literature and are therefore included in this study as well:

- $\quad$ Gender (MALE)

- $\quad$ Race (AFRICAN (B) and other races as referenced

- $\quad$ Age (TWENTIES, THIRTIES, FORTIES, OVER50, under twenty as referenced). In this survey, age was not a continuous variable and was categorised (Nielsen et al., 2010: 728); therefore, it could not be treated as non-linear.

- $\quad$ Education (PRIMARY, SECONDARY, COMPSEC (secondary school completed, no schooling as referenced)

- $\quad$ Marital status (MARRIED, DIVORCED, single as referenced)

\section{Conventional Economic Variables}

In this study, income and employment, specifically pertaining to the day labourers in South Africa and not of the country, as proposed by Knight et al. (2009), are used. In their study, Knight et al. (2009) determined the wellbeing of people in rural China and they used the per capita income and employment rate in the country. In this study, we are looking at the specific informal sector of day labourers. The income variable is the log of the wage in a good week (GOODWEEK) and employment variables are previously employed full-time (FULLTIME), looking for a full-time job (LOOKFULTIME), and have you turned down a job (TURNDOWN). The employment variables are important in this scenario given the significant number of more than 50 percent of the respondents who did previously have a full-time job before becoming day labourers (Blaauw, 2010). The literature review provided evidence of the negative effect that individual unemployment can have on subjective well-being (Winkelmann, 2009: 421). As a result, it is imperative to include the employment variables in the analysis.

\section{Comparison Variables}

According to Mentzakis and Moro (2009), current income, with regard to past circumstance and aspirations, forms the subjective perception of the financial situation of the respondent. Knight et al. (2009) also indicate the importance of comparison variables. This study offers a unique opportunity to study these in an informal context. The following questions incorporate past circumstances and future aspirations as envisaged by Mentzakis and Moro (2009): 1) Are job opportunities better at this site? (JOBSBETTERTHISITE) and 2) Do you have enough food? (FOOD)

Again, the unique nature of this labour market renders it an acceptable comparison variable. Better job opportunities do not always lead to being hired more often, given that more day labourers flock to these sites as soon as the site's reputation for 'having better opportunities' becomes known. However, this very possibility makes the day labourer feel better. It does not guarantee a higher income, however. The change in the income variable (GOODWEEK) was also included as a comparison variable (CHANGE). These variables are primarily a comparison of an individual at different times or with other day labourers that the respondents know. 


\section{Community Variables And Attitudinal Variables}

Attitudes are mostly endogenous, explaining observed and unobserved characteristics, and exploring hidden aspects of the personality (Knight et al., 2009). The attitudinal variables are an attempt to control for personality, which affects subjective well-being. Although one can perhaps argue that economists do this quite badly, it is common in the literature and, for this reason, was incorporated. The attitudinal and community variables are combined in this study. Knight et al. (2009) used different provinces as community variables. In this study, the focus will only be on the well-being of day labourers in South Africa as a whole, and future research will concentrate on well-being in different provinces. The attitudinal and community variables are: 1) Have you incurred an injury? (INJURY), 2) Do you have a support group? (SUPPORT), and 3) Do you stay with family? (STAYFAMILY). These questions can inform the psychological state of mind or attitude toward their perception of their job or situation of the day labourer.

The expected signs of these explanatory variables are presented in Table 3 below.

Table 3: The Expected Signs Of The Variables

\begin{tabular}{|c|c|c|}
\hline & Expected sign & Reason \\
\hline \multicolumn{3}{|l|}{ Basic Variables } \\
\hline AFRICAN & Irrelevant & Most day labourers are African. \\
\hline MALE & Irrelevant & Most day labourers are male. \\
\hline PRIMARY & + & Education on primary level does not affect SWB negatively. \\
\hline SECONDARY & + & Education on secondary level not completed does not affect SWB negatively. \\
\hline COMPSEC & - & You expect more from life when you have completed secondary school. \\
\hline MARRIED & + & Knight et al. (2009) found that people who are married are happier. \\
\hline DIVORCED & - & One would expect the sign to be negative on psychological grounds. \\
\hline TWENTIES & - & $\begin{array}{l}\text { Age usually non-linear with a U-shape. Will expect that the younger the day } \\
\text { labourer, the less happy he will be since he is looking for a better life. One } \\
\text { must remember that this age group is the one where the most productive years } \\
\text { of a nation's workforce and the individual's work life are supposed to be } \\
\text { (Gonzo and Plattner, 2003: 47). Spending it in this form of precarious } \\
\text { employment is therefore bound to be reflected in unfulfilled expectations and } \\
\text { feelings of unhappiness. Older people, on the other hand, are negative } \\
\text { because they know it is difficult to enter the formal job market, creating } \\
\text { further feelings of despair and self-doubt. }\end{array}$ \\
\hline THIRTIES & - & See above \\
\hline FORTIES & - & See above \\
\hline OVER50 & + & See above \\
\hline \multicolumn{3}{|l|}{ Economic Variables } \\
\hline GOODWEEK & + & If you had a good week's wage, you will probably feel positive. \\
\hline FULLTIME & - & $\begin{array}{l}\text { If you previously had a full-time job you will probably be negative about } \\
\text { being a day labourer, as the wage income in the formal economy will in all } \\
\text { probability be much higher than what can be obtained in the informal day } \\
\text { labour market. }\end{array}$ \\
\hline LOOKFULTIME & - & $\begin{array}{l}\text { If you are currently looking for a full-time job it is assumed that you are } \\
\text { unhappy with your current situation }\end{array}$ \\
\hline TURNDOWN & - & $\begin{array}{l}\text { Previous literature shows that the main reason why a day labourer will turn } \\
\text { down an employment opportunity is when the wage offered by the employer } \\
\text { is too low, leading to further dejection and despair. The expectation, then, is } \\
\text { that this will be negative. }\end{array}$ \\
\hline \multicolumn{3}{|l|}{ Comparison Variables } \\
\hline JOBSBETTERTHISITE & + & $\begin{array}{l}\text { This is a comparison with oneself or with other day labourers. If you feel it is } \\
\text { better at this site than your previous site, you will feel you are better off. } \\
\text { Better job opportunities do not always lead to being hired more often, given } \\
\text { that more day labourers flock to these sites as soon as the site's reputation for } \\
\text { 'having better opportunities' becomes known. However, this very possibility } \\
\text { makes the day labourer feel better. }\end{array}$ \\
\hline FOOD & + & If you have food, you will feel more positive about your job (comparison with \\
\hline
\end{tabular}




\begin{tabular}{|l|c|l|}
\hline CHANGE & + OR - & $\begin{array}{l}\text { oneself or other day labourers). } \\
\text { whether the change is negative or positive. }\end{array}$ \\
\hline $\begin{array}{l}\text { Attitudinal and Community } \\
\text { Variables }\end{array}$ & - & $\begin{array}{l}\text { If you incurred an injury, you will probably have a negative attitude toward } \\
\text { your job and your situation. }\end{array}$ \\
\hline INJURY & + & $\begin{array}{l}\text { If you are part of a group of day labourers who support each other, you will } \\
\text { have a positive attitude. }\end{array}$ \\
\hline SUPPORT & + & \begin{tabular}{l} 
If you are staying with your family, you will have a positive attitude. \\
\hline STAYFAMILY
\end{tabular} \\
\hline
\end{tabular}

\section{The Results Of The Objective And Subjective Functions Of Well-Being}

It may well be that people with higher levels of SWB are people with inherent characteristics that may lead them to work harder, earning more income in the process. This endogeneity problem is, in most cases, the result of not all variables being included in a data set one uses to control for this. Examples include personal characteristics and variables influencing the early life of the respondent (Clark et al., 2008). All data sets have this problem and an instrumentation procedure can, in principle, be used to address the likely endogeneity of income in a happiness equation (Kingdon and Knight, 2004: 15).

The income variable, log of the wage in a good week (GOODWEEK), will be instrumented because of endogeneity problems that occur with income when estimating SWB functions (Senik, 2005: 46; Kingdon and Knight, 2004: 15). The Hausman test for endogeneity indicated that the income variable (GOODWEEK) is indeed endogenous. Furthermore, the J-statistic probability was 0.0 and indicated the rejection of the null hypothesis, indicating endogeneity of the variable (see Appendix for results). The log of the lowest wage (LOWWAGE) and months as a day labourer (MONTHS) were used as instruments. The F-statistics are presented in the Appendix (Bound, Jaegar, and Baker, 1995). The over-identifying restriction is one since there are two Instrumental Variables (Wooldridge, 2003). Testing for over-identifying restrictions showed that both the Instrumental Variables are exogenous. This was confirmed with the othogonality test $-\mathrm{C}$ test. The p-values of the J-statistic were $>0.05$ and showed acceptance of the null hypothesis (see Appendix for results). The results of these tests comply with the conditions for valid instruments; i.e, $\operatorname{Cov}(z, u)=0$ and $\operatorname{Cov}(z, x \neq 0)$ (Wooldridge, 2003). Second-order tests on the regressions were done and corrected accordingly. The results of the estimations are compared in Table 4.

Table 4: Comparing The Well-being Functions

\begin{tabular}{|c|c|c|c|c|}
\hline \multirow[b]{2}{*}{$\mathrm{N}=2643$} & \multicolumn{2}{|c|}{ Objective Function (OLS) } & \multicolumn{2}{|c|}{ Subjective Function (Probit) } \\
\hline & Best Wage $^{* * * * *}$ & T-statistic & Good or Bad $* * * *$ & z-statistic \\
\hline \multicolumn{5}{|l|}{ Basic Variables } \\
\hline AFRICAN & 0.05 & 0.91 & -0.01 & -0.08 \\
\hline MALE & 0.04 & 0.66 & -0.43 & $-2.16 * *$ \\
\hline PRIMARY & 0.10 & $1.74 *$ & -0.29 & $-1.81 *$ \\
\hline SECONDARY & 0.14 & $2.24 * *$ & -0.11 & -0.68 \\
\hline COMPSEC & 0.03 & 0.40 & -0.03 & -0.15 \\
\hline MARRIED & 0.02 & 0.64 & 0.01 & 0.10 \\
\hline DIVORCED & -0.12 & $-1.89 *$ & 0.16 & 1.01 \\
\hline TWENTIES & -0.01 & -0.16 & -0.22 & $-2.12 * *$ \\
\hline THIRTIES & -0.02 & -0.59 & -0.12 & -1.10 \\
\hline FORTIES & 0.03 & 0.57 & 0.00 & 0.00 \\
\hline OVER50 & 0.00 & 0.06 & -0.12 & -0.65 \\
\hline \multicolumn{5}{|l|}{ Economic Variables } \\
\hline $\begin{array}{l}\text { GOODWEEK (Instruments: lowest } \\
\text { wage and months) }\end{array}$ & 1.27 & $3.98 * * *$ & 0.43 & $4.75 * * *$ \\
\hline FULLTIME & 0.07 & $2.56^{* * *}$ & -0.26 & $-3.59 * * *$ \\
\hline LOOKFULTIME & 0.01 & 0.11 & -0.11 & -0.60 \\
\hline TURNDOWN & -0.15 & $-3.39 * * *$ & 0.00 & -0.03 \\
\hline \multicolumn{5}{|l|}{ Comparison Variables } \\
\hline JOBSBETTERTHISITE & -0.51 & $-2.55 * * *$ & 1.86 & $21.56 * * *$ \\
\hline
\end{tabular}




\begin{tabular}{|l|c|c|c|c|}
\hline FOOD & -0.04 & -1.13 & 0.53 & $7.34 * * *$ \\
\hline CHANGE & -0.38 & -0.88 & -0.22 & $-3.89 * * *$ \\
\hline Attitudinal Variables & & & & \\
\hline INJURY & -0.12 & $-2.72 * * *$ & 0.03 & 0.28 \\
\hline SUPPORT & 0.19 & $4.82 * * *$ & -0.15 & $-1.91^{*}$ \\
\hline STAYFAMILY & 0.14 & $3.96 * * *$ & -0.15 & $-2.08^{* *}$ \\
\hline R squared & & 0.53 & & 0.55 \\
\hline
\end{tabular}

$* * *, * * * *$ is the 99,95 and $90 \%$ significance levels respectively; $* * * * a v e r a g e$ marginal effects

Source: E-views estimates

\section{Objective Function}

The objective function was estimated with the 2 SLS method and the income variable was instrumented with lowest wage and months of day labouring. Most of the signs (significant coefficients) were in line with expectations, except the question "Are jobs better at this site?" which recorded a negative sign. If a day labourer previously had a full-time job, previously it recorded a positive sign. This observation is contrary to a priori considerations. Closer scrutiny of the day labour market reveals this as quite plausible, however. Although the job opportunities may be experienced as better at the current hiring site, this improvement may be marginal and the observed income uncertainty remains basically the same. As this is the objective function and the wages per site and income earned change only marginally, this is not experienced by the day labourer as any real improvement in his well-being. In fact, it may add to a feeling of disappointment and disillusionment among day labourers. This further highlights the importance of income as a determinant of SWB in poor communities.

The positive sign of when a day labourer had a full-time job earlier can possibly be explained by the fact that, theoretically, the income earned might be higher than what a full-time job can offer with the level of schooling attained by the day labourer. The evidence on income suggests the opposite, however. A more plausible explanation may therefore be that having had a full-time job in the past provided some form of vocational training that is now increasing the day labourer's chances of securing temporary employment and income in the informal economy.

The contributions of the significant determinants are primary and secondary education, which contributes 10 and 14 percent to the SWB of the day labourer, respectively. Being divorced decreases the SWB by $12 \%$. A good week's wage increases SWB by $100 \%$, being a full-time employee previously increases subjective well-being (SWB) by 7\%, turned down a job decreases SWB by 15\%, and jobs better at this site decreases the SWB by $51 \%$. SWB decreases by $12 \%$ if an injury occurred on the job, while being part of a support group increases SWB by $19 \%$. If a day labourer lives with his family, the SWB increases by $14 \%$. This is no surprise, as a significant number of the day labourers move to urban locations in search of employment and do not see their family on a regular basis. Day labourers stated this disconnect as an important concern in their lives. Those who are able to live with family will experience an improvement in well-being. Furthermore, living with family implies that potentially there are alternative income sources available to the day labourer. The day labourer's spouse/partner may be working or income in the form of a government grant may be received.

The main determinants of the objective function are education (primary and secondary), almost all the economic variables (good week's wage, full-time job, and turn down a job), and the attitudinal variables (injury, support group, and staying with family). The comparison variable 'are jobs better at this site' was also a determinant, but in a negative way. The main contributors to the objective function are the economic and attitudinal variables.

\section{Subjective Function}

The dependent variable of the subjective function is binary; therefore, a probit model was fitted to the data and the income variable was instrumented with low wage and months of being a day labourer. All the significant coefficients' signs were in line with expectations, except primary schooling and staying with family with negative signs (see explanation below). The contributions of the determinants to SWB are a decrease of 43, 29, and 22 percent in the probability if you are male, with primary schooling or in the twenties age group, respectively. A good week's wage increases the probability of SWB by $43 \%$ and being a full-time employee previously decreases SWB 
by $26 \%$. Again, this confirms the notion that having lost their jobs in the formal economy, day labourers engage in day labouring as a survivalist activity and out of desperation. If jobs are better at this site and you have food, it increases the probability of SWB by 100 and 53 percent, respectively. If there is a change in income for a good week, it will have a $22 \%$ change in probability of SWB. If you live with family, it decreases the probability of SWB by $15 \%$. This result can potentially be explained by calling on the experience obtained during the interviews with the day labourers and the observed uncertainty in the income earned by the day labourers. In bad months, day labourers are not always able to provide for their families. To bear the impact of this is more difficult if the day labourer is living with family and "... must face them every day with empty hands ..." In a strange way, it may be easier to bear that you cannot provide for your dependants if you do not see them every day; some day labourers stated as much during interviews. This is an important social aspect that requires closer inspection through qualitative research via detailed case studies.

The main determinants of the subjective function are race, primary schooling, the twenties age group, the economic variables (good week's wage and full-time job) and all the comparison variables (having food, are jobs better at this site and the change in income). One attitudinal determinant is staying with family. The main contributors to SWB of a day labourer in this subjective function are the economic and comparison variables.

\section{Comparing The Subjective And Objective Function}

The findings of this analysis are that economic variables, such as employment and income, do play an important part in well-being. This was the case for the objective as well as the subjective function.

Income in a good week had a positive and significant impact in both the functions. This is in line with other research. Cummins (2000: 151) found that personal income is a very important element in the sustainability of SWB, particularly for poor people. Diener, Diener, and Diener (2009: 66) found that income, individualism, human rights, and societal equality determine SWB. Similarly, in a study of taxi drivers in Beijing, Nielsen et al. (2010: 728) found that despite earning low wages, their well-being was within the normative range. They also found that personal relationships and feeling part of a community, as well as income, play a role in well-being (Nielsen, et al. 2010: 731), especially when the individual leads a hard life on objective indicators.

In a study determining the determinants of subjective well-being in South Africa, Kingdon and Knight (2007: 17) found that relative income plays a role in well-being, especially comparator income. It suggests that people choose their groups of comparison by reference to social proximity, in South Africa specifically by race. The comparative variables were significant in the subjective function, and since the largest part of the sample is African, this confirms the findings by Kingdon and Knight (2007). Mentzakis and Moro (2009: 147) also found that relative income is important in determining subjective well-being.

An important difference between these two functions is the sign of having previously been employed fulltime. The sign for the objective function is positive and the sign for the subjective function is negative (expected sign), and they are both significant. One possible explanation for the positive sign might be that when the day labourer earns more income as a day labourer than as a full-time employee, the sign might be positive. The fact that the person does not have a full-time job anymore does not necessarily lead to a feeling of unhappiness with his current status in terms of income earned. An analysis of the income earned by day labourers shows that their income levels are very low, on average, and uncertain. Therefore, a more plausible explanation in this case is the relief experienced by day labourers - they might have lost their full-time employment but are economically active again and at least some income is earned in this informal economy activity. The fact remains that day labouring in South Africa is mostly a catchment area for people who have lost their jobs, with very little prospect of a return to the formal economy (Blaauw, 2010). Most respondents testified that they would prefer formal economy employment and the certainty it provides. In the subjective function, therefore the person might feel that life would be better if they were more certain about a job and income irrespective of the income earned; hence, the negative sign.

The other difference between these two functions was between the comparison and attitudinal variables. In the subjective function, the comparison variables played a larger part - because of the role that relative income plays in SWB (Mentzakis and Moro, 2009, and Kingdon and Knight, 2007). In the objective function, the attitudinal 
variables were more important. Both these functions found that the economic variables are important. This confirmed the findings by Nielsen et al. (2010), Diener et al. (2009) and Cummins (2000) by showing that personal income is important in a poor community. These findings indicate that subjective and objective measures of wellbeing both capture valuable characteristics of SWB in a poor community. This opens up the possibility of further indepth studies into social isolation as a determining factor for SWB in poor communities, along the lines of the work of Thompson and Heller (1990).

\section{CONCLUDING REMARKS, POSSIBLE POLICY IMPLICATIONS AND A FUTURE RESEARCH AGENDA}

Many studies in subjective well-being investigate the well-being of geographical areas or specific gender groups within countries. Studies on specific sectors of the economy are much less common and studies on specific informal labour markets even less so. The contribution of this study is to fill this gap in the literature by looking at a specific informal sector activity; namely, that of day labouring in South Africa. The results of the study provided insight into the subjective well-being experienced by the participants in the informal economy activity of day labouring in South Africa. The unique characteristics of this informal labour market made it possible to estimate an objective and subjective well-being function which, in part, address the debate around whether income can be deemed a measure of well-being.

The objective and subjective well-being functions showed that economic variables, such as employment and income, do play an important part in well-being. The results may appear obvious or even tautological. However, as Cummins (2000: 134-135) points out, the specific contribution of low income to well-being, when there is poor health and prolonged periods of unemployment, is uncertain. The results confirm the hypothesis of the importance of income for both the objective and subjective well-being of those living in extreme poverty.

The difference between these two functions (OLS) was that attitudes (injuries, being part of a support group and living with family) do play a role in the objective function and comparison variables (having food, change in income and are jobs better at this site) are more important in the subjective function. These findings indicate that subjective and objective measures of well-being both capture valuable characteristics of SWB in a poor community.

It is also clear from the results that economics, as a discipline, could benefit significantly by utilising more qualitative research methods to supplement the traditional quantitative methods used. Failure of policy-makers to appreciate subjective well-being as a social indicator can, in fact, hinder development. Diener et al. (2009: 164) have shown how an analysis of unemployment incorporating well-being measures has the potential to increase our knowledge and understanding beyond what can be obtained using macro-economic measures on their own. This inclusive type of analysis will provide a more nuanced insight into the decision-making behaviour of individual economic agents in various sectors of the economy. Policy decisions will be better informed as a positive externality of extending the scope of accepted methodology in the discipline. The design of public policy will benefit, as it will be possible to better appraise policy interventions in terms of their effects on the well-being of the target population.

The results of this paper indicate that they are particularly applicable to social policy focusing on participants in the informal economy. A systematic accounting of well-being can inform social policy actions to improve the well-being of these individuals. The results of the study identified the role of injuries and being part of a support group as affecting the objective well-being of day labourers in South Africa. Social policy can focus on these areas. The development of day labour centres, along the lines of what has been done in the United States, can serve as a practical step in improving the well-being of day labourers in South Africa. Centres like this can provide a safe area with toilet and washing facilities. Apart from basic services, the centre can be the location from where a range of legal and other social services can be provided. This can ensure improved legal recourse in the event of non-payment of wages by an employer or injuries at the workplace. Training can also take place at these centres in order to improve the skills base of the day labourers, enabling them to earn better wages.

Apart from policy implications, the results of the study open up a new research agenda. The role of social relationships in the well-being of day labourers requires further focused research. Other important research opportunities to expand this field of research for the South African economy exist. Pertinent research questions that 
remain to be answered include possible geographical differences in the well-being of day labourers in South Africa. The rural/urban divide, in terms of the subjective well-being of day labourers in South Africa, also requires focused investigation. Recent xenophobic attacks on foreign workers in South Africa have raised the question of whether the subjective well-being of South African, and that of foreign day labourers differ significantly, and, if so, what the reasons for this are. Ideally, follow-up research in the form of repeated studies over time can show how these aspects change and affect the well-being in this growing informal labour market in a country plagued by high levels of unemployment, poverty and inequality.

\section{ACKNOWLEDGEMENT}

We wish to acknowledge and express our sincere gratitude to Professor Russell Smyth (Head of the Department of Economics at Monash University Australia) for his extremely valuable comments on an earlier version of this paper as well as the valuable comments of an anonymous reviewer of Economic Research Southern Africa (ERSA) on an earlier draft. The authors wish to thank Economic Research Southern Africa (ERSA) for financial assistance with this research project. The usual disclaimer naturally applies.

\section{AUTHOR INFORMATION}

Phillip Blaauw is an associate professor of Economics at the University of Johannesburg, South Africa. His research interests include labour economics, the informal economy, the dynamics of informal labour markets and local economic development. He has published in these fields in local South African as well as international journals. E-mail: pfblaauw@uj.ac.za (Corresponding author)

Ilse Botha holds a D.Com (Economics) degree from the University of Johannesburg - previously Rand Afrikaans University. Before entering academia, she worked as an economist at a South African bank. She is currently a senior lecturer at the Department of Finance and Investment Management at the University of Johannesburg where she teaches and supervises at the post graduate level. She is involved in various research projects and her current research explores various time series techniques and business cycle economics. E-mail: ilseb@uj.ac.za

Rinie Schenck is a National Research Foundation (NRF)-rated professor of Social Work at the University of the Western Cape, South Africa. Her research interest includes poverty, people in the informal economy, research on student matters, community development, social policy, rural social work and the working conditions of social workers. She has published extensively in these fields in local South African as well as international journals. E-mail: cschenck@uwc.ac.za

Christie Schoeman is a senior lecturer in Economics at the University of Johannesburg, South Africa. His research interests include monetary economics, financial economics and economic behaviour under conditions of uncertainty. He has published in these fields in local South African as well as international journals. E-mail: christies@uj.ac.za

\section{REFERENCES}

1. Blaauw, P.F. (2010). The socio-economic aspects of day labouring in South Africa. Unpublished DComthesis, Department of Economics \& Econometrics, University of Johannesburg, South Africa.

2. Blaauw, D., Louw, H. \& Schenck, R. (2006). The Employment History of Day Labourers in South Africa and The Income They Earn - A Case Study of Day Labourers in Pretoria, South African Journal of Economic and Management Sciences, NS 9(4) 458-71.

3. Blaauw, P.F. \& Krugell, W.F. (2011). Micro-evidence on day labourers and the thickness of labour markets in South Africa. Paper presented at the $4^{\text {th }}$ Public Economics Workshop, hosted by Economic Research Southern Africa (ERSA), Stellenbosch Institute for Advance Studies (STIAS), University of Stellenbosch Stellenbosch, 3 - 4 May 2011.

4. Bless, C. \& Higson-Smith, C. (1995). Fundamentals of Social Research Methods - an African Perspective, $2^{\text {nd }}$ edition. Cape Town: Juta. 
5. Botha, F. \& Booysen, F. (2011). The gold of one's ring is not far more precious than the gold of one's heart: reported happiness among married and cohabiting South African adults. Paper presented at the biannual conference of the Economic Society of South Africa (ESSA), University of Stellenbosch, South Africa, 4 - 7 September 2011.

6. Bound, J., Jaegar, D.A. \& Baker, R.M. (1995). Problems with Instrumental Variables Estimation When the Correlation between the Instruments and the Endogeneous Explanatory Variable is Weak. Journal of the American Statistical Association, 90(430) 443-450.

7. Clark, A.E., Frijters, P. \& Shields, M.A. (2008). Relative income, happiness and utility: an explanation for the Easterlin paradox and other puzzles. Journal of Economic Literature, 46(1) 95-144.

8. Cramm, J.M., Møller, V. \& Nieboer, A.P. (2010). Improving subjective well-being of the poor in the Eastern Cape. Journal of Health Psychology, 15(9) 1012-1019.

9. Cummins, R.A. (2000). Personal income and subjective well-being: a review. Journal of Happiness Studies, 1, 133-158.

10. De Vos, A.S., Strydom, H., Fouche, C.B. \& Delport, C.S.L. (2004). Research at the grass roots: For the social sciences and human service professions, $2^{\text {nd }}$ edition. Pretoria: Van Schaik.

11. Demir, M. \& Weitekamp, L.A. (2007). I am so happy cause today I found my friend: friendship and personality as predictors of happiness. Journal of Happiness Studies, 8, 181-211.

12. Diener, E., Sandvik, E., Seidlidtz, L. \& Diener, M. (1993). The relationship between income and subjective well-being: relative or absolute? Social Indicators Research, 28, 195-223.

13. Diener, E., Suh, E.M., Lucas, R.E. \& Smith, H.L. (1999). Subjective well-being: three decades of progress. Psychological Bulletin, 125, 276-302.

14. Diener, E., Diener, M. \& Diener, C. (2009). Factors predicting subjective well-being of Nations. Social indicators research series, 38, DOI 10.10077978-90-481-2352-0_3, 43-70.

15. Diener, E., Lucas, R.E., Schimmack, U. \& Helliwell, J.F. (2009). Well-being for public policy. New York: Oxford University Press.

16. Dolan, P., Peasgood, T. \& White, M. (2008). Do we really know what makes us happy? A review of the economic literature on the factors associated with subjective well-being, Journal of Economic Psychology, 29, 94-122.

17. Easterlin, R. (1974). Does economic growth improve the human lot? Some empirical evidence. In P.A. David \& M.W. Reder (Eds.), Nations and households in economic growth: Essays in honour of Moses Abramovitz (pp. 89-125). New York: Academic Press.

18. Easterlin, R.A. (2001). Editorial: Subjective well-being and economic analysis: a brief introduction. Journal of Economic Behavior \& Organization, 45 225-226.

19. Ebrahim, A., Botha, F. \& Snowball, J. (2011). The determinants of happiness among race groups in South Africa. Paper presented at the biannual conference of the Economic Society of South Africa (ESSA), University of Stellenbosch, South Africa, 4 - 7 September 2011.

20. Frey, B. \& Stutzer, A. (2002). What can economists learn from happiness research? Journal of Economic Literature, 40, 402-435.

21. Gao, W. \& Smyth, R. (2010). What keeps China's migrant workers going? Expectations and happiness among China's floating population. Monash University, Department of Economics Discussion Paper, $14 / 10$.

22. Gonzo, W. \& Plattner, I.E. (2003). Unemployment in an African country: a psychological perspective. Windhoek: University of Namibia Press.

23. Greyling, T. (2011). Measuring and understanding the well-being of the Gauteng City-region's population. Paper presented at the biannual conference of the Economic Society of South Africa (ESSA), University of Stellenbosch, South Africa, 4 - 7 September 2011.

24. Harmse, A., Blaauw, P.F. \& Schenck, R. (2009). Day Labourers, Unemployment and Socio-economic Development in South Africa, Urban Forum, 20(4) 363-377.

25. Helliwell, J F. \& Barrington-Leigh, C.P. (2010). Measuring and understanding subjective well-being. NBER Working Paper 15887, Cambridge, MA.

26. Hirata, J. (2011). Happiness, ethics and economics. New York: Routledge.

27. Knight, J. \& Gunatilaka, R. (2008). Aspirations, adaption and subjective well-being of rural-urban migrants in China. Department of Economics, University of Oxford, Discussion Paper No. 381. 
28. Knight, J., Song, L. \& Gunatilaka, R. (2009). Subjective well-being and its determinants in rural China. China Economic Review, 20, 635-649.

29. Kingdon, G.G. \& Knight, J. (2003). Well-being poverty versus income poverty and capabilities poverty? The Centre for the Study of African Economies Working Paper Series, Working Paper 199.

30. Kingdon, G.G. \& Knight, J. (2004). Subjective well-being poverty versus income poverty and capabilities poverty, Economic and Social Research Council, WPS003.

31. Kingdon, G.G. \& Knight, J. (2007). Community, comparisons and subjective well-being in a divided society. Journal of Economic Behaviour and Organisation, 64(1) 69-90.

32. Louw, H. (2007). Men at the margins: Day labourers at informal hiring sites in Tshwane. Unpublished PhD-thesis, Department of Social Work, University of South Africa, Pretoria.

33. Mentzakis, E. \& Moro, M. (2009). The poor, the rich and the happy: exploring the link between income and subjective well-being. Journal of Socio-Economics, 38 147-158.

34. Møller, V. \& Schlemmer, L. (1989). South African Quality of Life: A Research Note. Social Indicators Research, 21(3) 279-291.

35. Møller, V. (1998). Quality of life in South Africa: Post-apartheid trends. Social Indicators Research, 43(12) 27-68.

36. Møller, V. \& Saris, W.E. (2001). The Relationship between Subjective Well-being and Domain Satisfactions in South Africa. Social Indicators Research, 55(1) 97-114.

37. Møller, V. \& Dickow, H. (2002). The Role of Quality of Life Surveys in Managing Change in Democratic Transitions: The South African Case. Social Indicators Research, 58(1-3) 267-292.

38. Nielsen, I., Paritski, O. \& Smyth, R. (2010). Subjective well-being of Beijing taxi drivers. Journal of Happiness Studies, 11, 721-733.

39. Rubin, A. \& Babbie, E. (1997). Research methods for social work, $3^{\text {rd }}$ edition. Pacific Grove: Brooks Cole.

40. Saunders, S.G. (2005). Estimates of the informal economy in South Africa: some macroeconomic policy implications. Unpublished DCom-thesis, Department of Economics \& Econometrics, University of Johannesburg, South Africa.

41. Schenck, R., \& Louw, H. (2005). An exploratory study on day labourers in Elardus Park Pretoria. Social Work/Maatskaplike Werk, 41(1) 84-95.

42. Senik, C. (2005). Income distribution and well-being: What can we learn from subjective data? Journal of Economic Surveys, 19(1) 43-63.

43. Theodore, N. (2009). On the Corner: Day Labor in the United States. Paper delivered at a staff seminar of the Department of Economics and Econometrics at the University of Johannesburg, 15 October 2009, University of Johannesburg, Johannesburg, South Africa.

44. Thompson, M.G. \& Heller, K. (1990). Facets of support related to well-being: uantitative social isolation and perceived family support in a sample of elderly women. Psychology and Aging, 5(4) 535-544.

45. Tiwari, M. (2009). Poverty and wellbeing at the "Grassroots"-How much is visible to researchers? Social Indicators Research, 90 127-140.

46. Vakalisa, N.C.G. (2005). Unemployment in South Africa on the rise: are the schools and universities to blame? Africa Education Review, 2(1) 40-58.

47. Valenzuela Jr., A., Theodore, N., Meléndez, E. \& Gonzalez, A.L. (2006). On the corner: Day labor in the United States. Los Angeles: UCLA.

48. Veenhoven, R. (1991). Is happiness relative? Social Indicators Research, 24 1-34.

49. Williams, T.A., Sweeney, D.J. \& Anderson, D.R. (2006). Contemporary Business Statistics. Cincinnati: Thomson South Western.

50. Winkelmann, R. (2009). Unemployment, social capital, and subjective well-being. Journal of Happiness Studies, 10 421-430.

51. Wooldridge, J.M. (2003). Introductory Econometrics. Ohio: Thomson South Western. 


\section{APPENDIX}

Endogeneity Test

Equation: EQ_OBFINAL

Specification: LOG(BESTWAGE) B MALE PRIMARY SECONDARY

COMPSEC MARRIED DIVORCED TWENTIES THIRTIES FORTIES

OVER50 LOG(GOODWEEK) FULLTIME LOOKFULTIME TURNDOWN

JOBSBETTERTHISITE FOOD INJURY SUPPORT STAYFAMILY C

Instrument specification: C B MALE PRIMARY SECONDARY COMPSEC

MARRIED DIVORCED TWENTIES THIRTIES FORTIES OVER50

FULLTIME LOOKFULTIME MONTHS TURNDOWN JOBSBETTERTHIS

ITE FOOD INJURY SUPPORT STAYFAMILY LOG(LOWWAGE)

Endogenous variables to treat as exogenous: LOG(GOODWEEK)

Difference in J-stats

\begin{tabular}{lcc} 
Value & df & Probability \\
\hline 434.8986 & 1 & 0.0000
\end{tabular}

J-statistic summary:

Restricted J-statistic

Unrestricted J-statistic

Value

436.9625

2.063985

Instrument Orthogonality C-test Test

Equation: EQ_OBFINAL

Specification: LOG(BESTWAGE) B MALE PRIMARY SECONDARY

COMPSEC MARRIED DIVORCED TWENTIES THIRTIES FORTIES

OVER50 LOG(GOODWEEK) FULLTIME LOOKFULTIME TURNDOWN

JOBSBETTERTHISITE FOOD INJURY SUPPORT STAYFAMILY C

Instrument specification: B MALE PRIMARY SECONDARY COMPSEC

MARRIED DIVORCED TWENTIES THIRTIES FORTIES OVER50

FULLTIME LOOKFULTIME MONTHS TURNDOWN

JOBSBETTERTHISITE FOOD INJURY SUPPORT STAYFAMILY

LOG(LOWWAGE) MONTHS

Test instruments: LOG(LOWWAGE)

\begin{tabular}{llcc} 
& Value & df & Probability \\
\cline { 2 - 4 } Difference in J-stats & 1.139108 & 1 & 0.2858
\end{tabular}

J-statistic summary:

Restricted J-statistic

Unrestricted J-statistic

\begin{tabular}{l} 
Value \\
\hline 1.139108 \\
0.000000
\end{tabular}


Instrument Orthogonality C-test Test

Equation: EQ_OBFINAL

Specification: LOG(BESTWAGE) B MALE PRIMARY SECONDARY

COMPSEC MARRIED DIVORCED TWENTIES THIRTIES FORTIES

OVER50 LOG(GOODWEEK) FULLTIME LOOKFULTIME TURNDOWN

JOBSBETTERTHISITE FOOD INJURY SUPPORT STAYFAMILY C

Instrument specification: B MALE PRIMARY SECONDARY COMPSEC

MARRIED DIVORCED TWENTIES THIRTIES FORTIES OVER50

FULLTIME LOOKFULTIME MONTHS TURNDOWN

JOBSBETTERTHISITE FOOD INJURY SUPPORT STAYFAMILY

LOG(LOWWAGE) MONTHS

Test instruments: MONTHS

\begin{tabular}{llcc} 
& Value & df & Probability \\
\cline { 2 - 4 } Difference in J-stats & 1.139108 & 1 & 0.2858
\end{tabular}

J-statistic summary:

Unrestricted J-statistic $\quad 0.000000$

Objective function 2SLS:

$\begin{array}{llll}\text { R-squared } & -0.140337 & \text { Mean dependent var } & 4.665406 \\ \text { Adjusted R-squared } & -0.149477 & \text { S.D. dependent var } & 0.499201 \\ \text { S.E. of regression } & 0.535212 & \text { Sum squared resid } & 750.5027 \\ \text { F-statistic } & 46.42591 & \text { Durbin-Watson stat } & 1.394488 \\ \text { Prob(F-statistic) } & 0.000000 & \text { Second-Stage SSR } & 378.8672 \\ \text { J-statistic } & 1.20 \mathrm{E}-34 & \text { Instrument rank } & 22\end{array}$

Subjective function 2 SLS

$\begin{array}{llll}\text { R-squared } & -1.661847 & \text { Mean dependent var } & 0.422407 \\ \text { Adjusted R-squared } & -1.683183 & \text { S.D. dependent var } & 0.494036 \\ \text { S.E. of regression } & 0.809252 & \text { Sum squared resid } & 1715.809 \\ \text { F-statistic } & 28.17365 & \text { Durbin-Watson stat } & 1.952078 \\ \text { Prob(F-statistic) } & 0.000000 & \text { Second-Stage SSR } & 257.1306 \\ \text { J-statistic } & 0.000000 & \text { Instrument rank } & 22\end{array}$


NOTES 